\title{
Basel III: Will Borrowing Money from Czech Banks Become More Expensive?
}

\author{
Milan Matejašák
}

\section{Introduction}

In Europe, Basel III is already in force. The very recent European legislative package, comprising Capital Requirements Directive IV (socalled CRD IV) and Capital Requirements Regulation (so-called CRR), has been in force since 1 January 2014. It represents a significant change for bankers because it puts the new global Basel III regulation into practice.

A number of effects is expected to follow from the implementation of this package and many of these effects are difficult to estimate. Dvořák (2010) predicts Basel III is likely to bring a number of positives, such as strengthening the quality and quantity of bank capital, strengthening the stability of the banking system and reducing the risk of systematic banking crisis. However, other effects may be less beneficial. Basel III puts significant pressure on profitability and return on equity and it leads banks to increase their risk appetite. Basel III critics argue that it may even destabilize well-capitalized banks in certain countries. For example, common worry is that foreign parent companies may "suck" capital and liquidity from well-capitalized Czech banks as a result of the worsening financial situation of the parent companies. Last but not least, there is a worry that loans for individual and corporate clients may get more expensive.

In this paper we aim to analyse the last-mentioned worry: that bank loans may become more expensive. Looking at Czech banks we pose two

\footnotetext{
\# The article is processed as an output of a research project Behavior of investment and credit instruments prices registered by the Internal Grant Agency of The University of Economics, Prague under the registration number IGA 87/2014.

PhDr. Milan Matejašák MSc. - Ph.D. Student; Department of Banking and Insurance, Faculty of Finance and Accounting, University of Economics, Prague, W. Churchill Sq. 4, 13067 Prague 3; Czech Republic; <xmatm37@vse.cz>.
} 
key questions: When the capital regulation is tightened, will loans in the Czech banks become more expensive? By how much can lending spreads increase? In order to answer these two key questions we will follow the methodology presented by King (2010). We estimate the required increase in banks' lending interest rates assuming that banks raise the interest rates (among other measures they can take) to prevent ROE from falling when the capital is increased.

The main benefit of this paper is that, to our knowledge, it is the first paper that tries to analyse the impact of Basel III on interest rates in the Czech Republic. The results of this paper are interesting not only for researchers, but also for clients of Czech banks.

The structure of this paper is as follows: the first chapter briefly summarizes new capital requirements and it presents the results of literature related to measuring the impact of tighter capital regulation in Europe and globally. In the second chapter we present mapping methodology of higher capital requirements on lending spreads. We introduce data on Czech banks as well. The third chapter presents the final results of our analysis; it gives us an answer to the question stated in the paper's title. The final chapter summarizes the analysis and it repeats the main findings.

\section{Higher capital requirements in Basel III}

Basel III brings a number of new measures, instruments and requirements. The key new requirement is strengthening the quality and quantity of capital. In this chapter we present it in more detail. Later in the chapter we summarize the findings of literature measuring the impacts of tighter regulation.

\subsection{Basel III brings higher capital requirement}

The financial crisis showed that not all banks had satisfactory capital levels. Moreover, some banks had capital of low quality, and so could not absorb the losses. Basel III reacts to both weaknesses. It requires banks to hold more capital of higher quality compared to Basel II. According to the new definition, capital comprises the following two components: going-concern Tier 1 capital and gone-concern Tier 2 capital. Tier 1 
Matejašák, M.: Basel III: Will Borrowing Money from Czech Banks Become More Expensive?

capital consists of Common Equity Tier 1 (CET 1) capital and Additional Tier 1 Capital.

CET 1 capital is the highest quality capital. Common shares and retained earnings must form the predominant part of CET 1 . The quantity of minimum levels is required as follows (Chart 1):

- CET 1 capital ratio of $4.5 \%$ of risk-weighted assets (RWA),

- Tier 1 capital ratio of $6 \%$ of risk-weighted assets,

- Total capital ratio of $8 \%$ of risk-weighted assets.

\section{Fig. 1: Basel III capital requirements}

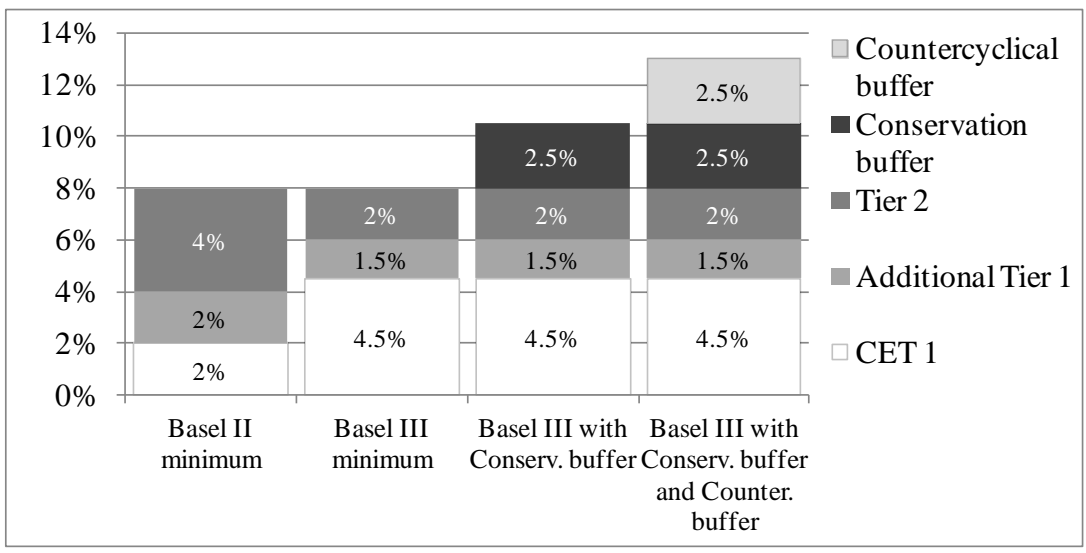

Source: BIS (2010), CNB (2013a), author.

Comparing Basel II and Basel III, the minimum total capital ratio remains at $8 \%$ of RWA. However, CET 1 capital ratio increases from $2 \%$ to $4.5 \%$ and additional Tier 1 capital ratio decreases from $2.0 \%$ to $1.5 \%$, leading Tier 1 capital ratio to increase from $4 \%$ to $6 \%$. The importance of Tier 2 capital decreases by reducing the ratio from $4 \%$ to $2 \%$ of RWA.

On top of these changes in Tier 1 and Tier 2 capital, Basel III introduces two new buffers: a capital conservation buffer of $2.5 \%$ and a countercyclical buffer of $0-2.5 \%$. Both buffers need to be covered by CET1 capital. As noted by Mandel and Tomšík (2011), additional capital conservation buffer implementation is logical because forcing banks to keep fixed $8 \%$ capital level leads to credit rationing during 
financial crisis. Additional capital surcharges of up to $3.0 \%$ for systemically important financial institutions (SIFIs) are effective as well. The surcharge needs to be covered by CET1 capital as well.

In October 2013, the Czech National Bank (CNB 2013a, CNB 2013b) decided it would not implement the countercyclical buffer gradually until 2019, as the original Basel III standard suggests. The CNB requires Czech banks to implement the buffer to the full value of $2.5 \%$ already in 2014. Related to the countercyclical buffer, the CNB (2013a) decided to set its value to $0 \%$ for the years 2014 and 2015. Moreover, the CNB decided that four banks in the Czech Republic were systematically important and it imposed SIFI surcharge from $1 \%$ to $3 \%$ CET1 capital for these four banks. These four systematically important banks are: ČSOB, Česká spořitelna, Komerční banka and UniCredit Bank.

To conclude, the Czech banks that are not systematically important, hence all banks apart from the four biggest ones should hold their capital levels above $10.5 \%$ in 2014 and 2015, if they do not want to face restrictions on dividend payment. The restrictions are applied if the capital falls below the $10.5 \%$ level. The $10.5 \%$ requirement consists of an $8 \%$ minimum and $2.5 \%$ capital conservation buffer. However, it is important to note that banks need to be prepared for an additional increase of $2.5 \%$ in countercyclical buffer if the CNB increases its value in the future.

The top four banks face a SIFI surcharge and they should be prepared for an increase in the countercyclical buffer too. Hence, they should hold their capital levels above $14.0 \%$ to $16.0 \%$. This includes $8 \%$ capital minimum, $2.5 \%$ conservation buffer, $2.5 \%$ countercyclical buffer and $1 \%$ to $3 \%$ SIFI surcharge.

\subsection{Literature review}

From a broad perspective, for example, Musílek (2011) describes summarizes the basic arguments (such as moral hazard, information asymmetry, imperfect competition, negative externalities) of mainstream financial theory why financial regulation is necessary. On the other hand, Mandel and Tomšík (2011) analyse the banking regulation from the economic theory's point of view. They explain that different schools of economic thought (Friedrich von Hayek and the Austrian school, Milton Friedman and monetarists or Hyman P. Minsky and post- 
Keynesian economists) have different opinion on banking regulation; however, all these schools of economic thought recommend at least some form of banking regulation.

In more detail, a number of authors have tried to estimate the impact of higher capital requirements on lending spreads; for example, King (2010), Kashyap, Stein and Hanson (2010), Slovik and Cournede (2011) or more recently Šútorová and Teplý (2013). Most of the analysis has been focused on banks in large regions, such as the Euro area, US banks or globally. Their samples usually include thousands of banks.

The findings are interesting. No matter what region, all authors conclude that an increase in capital requirement leads to an increase in loan interest rates. However, their estimates of magnitude differ, sometimes a lot. For example, when looking at US banks Kashyap, Stein and Hanson (2010) state that one percentage point increase in capital leads to an increase in loan interest rates by 2.5 basis points (bps), while Roger and Vlček (2011) estimate a much higher impact, around 60 bps. Alternatively, for the EU banks Š́torová and Teplý (2013) estimate an increase of 18.8 bps in lending spreads while Roger and Vlček (2011) estimate totals 65 bps. For the comparison of results see table 1 .

\section{Tab. 1: Impact of 1 percentage point increase in the capital ratio on loan interest rate}

\begin{tabular}{|l|l|r|}
\hline \multicolumn{1}{|c|}{ Authors } & \multicolumn{1}{c|}{ Region } & \multicolumn{1}{c|}{$\begin{array}{c}\text { Increase in loan } \\
\text { interest rate in basis } \\
\text { points }\end{array}$} \\
\hline Sútorová and Teplý (2013) & EU & $18.8 \mathrm{bps}$ \\
\hline Sun, Hoon and Wonhong (2012) & Globally & $0.1-29.7 \mathrm{bps}$ \\
\hline Roger and Vlček (2011) & $\begin{array}{l}\text { USA, } \\
\text { Euro area }\end{array}$ & $\begin{array}{r}\text { USA: } 60 \mathrm{bps} \\
\text { Euro area: } 65 \mathrm{bps}\end{array}$ \\
\hline Slovik and Cournede (2011) & USA, & $\begin{array}{r}\text { USA: } 23.4 \mathrm{bps} \\
\text { Euro area: } 14.3 \mathrm{bps}\end{array}$ \\
\hline Kashyap, Stein and Hanson (2010) & Euro area & $2.5 \mathrm{bps}$ \\
\hline Eliott (2010) & USA & $19 \mathrm{bps}$ \\
\hline King (2010) & Globally & $15 \mathrm{bps}$ \\
\hline
\end{tabular}

Source: Š́utorová and Teplý (2013), author. 
In contrast to the literature listed in table 1 we have decided not to include all banks from a chosen region; in our case not all banks from the Czech Republic are included in our sample. We have chosen to include only those banks that are under regulatory pressure. We assume that banks with high capital ratios have little motivation to increase their capital in order to meet regulatory standards, as their capital levels are already above the regulatory requirements. Hence, our approach is that we do not include all banks from the Czech Republic but only a subset of banks, those banks that are under regulatory pressure. We explain our approach in more detail in the following chapter 2.

\section{Methodology and Data}

In chapter 2 we present the mapping methodology used to estimate the impact of one percentage point increase in capital on lending spreads. The analysis presented here, while intended to be broadly realistic, is necessarily simplified. The remainder of this chapter provides data description and financial statements of a representative bank.

\subsection{Methodology}

This section explains the mapping methodology of higher capital requirement to interest rate spread. The mapping methodology was firstly introduced by King (2010) and later was used by others, for example, Sun, Hoon and Wonhong (2012). As noted by King (2010), the methodology does not consider the impact on lending spreads during the transition stage, only during the steady state.

The mapping exercise begins with the stylized balance sheet for a representative bank (see equations 1 and 2). Bank assets (A) consist of cash (C), interbank claims (IBC), trading assets (TrA), loans (Lo), investments in securities (Inv) and other assets (OA). The major part of assets is loans, which consist of mortgage loans, corporate loans and consumer loans. However, this differentiation of loan types is not important in this mapping exercise, so we will treat them equally as one type of loan. Bank liabilities (L) consist of deposits (Dep), interbank funding (IBF), trading liabilities (TrL), debt (D) and other liabilities (OL). Debt consists of short-term borrowings, senior debt and subordinated borrowing. 
Matejašák, M.: Basel III: Will Borrowing Money from Czech Banks Become More Expensive?

$$
\begin{aligned}
& A=C+I B C+\operatorname{Tr} A+L o+I n v+O A . \\
& L=D e p+I B F+\operatorname{Tr} L+D+O L .
\end{aligned}
$$

Further, when looking at a representative bank's profit and loss statement, its net income (NI) consists of four major categories: net interest income, net non-interest income (NII), operating expenditure $(\mathrm{OE})$ and tax. When looking at net interest income in more detail, it may be divided into three broad categories: loans interest income (LII), other interest income (OII) and interest expense (IE) (see equation 3).

$$
N I=[(L I I+O I I-I E)+N I I-O E] \cdot(1-\operatorname{tax}) .
$$

Loans interest income (LII) is generated by loans (Lo), interbank claims (IBC) and investments (Inv). Interest expense (IE) is generated by deposits (Dep), interbank funding (IBF) and debt (D) which from the maturity criterion may be divided into short term debt (maturing within one year) and long term debt (maturity over one year). This maturity debt split with a one year threshold is important in order to have our estimates of lending spread increase more precise, as we will explain later.

$$
D_{t}=D_{t} \cdot \beta_{t}+D_{t} \cdot\left(1-\beta_{t}\right) \text {, }
$$

where $\beta_{t}=$ portion of debt maturing within one year,

Non-interest income (NII) consists of fees, commissions and trading income, which is generated by trading assets $(\operatorname{TrA})$ and trading liabilities (TrL). Operating expenditure (OE) is mainly personnel expense, administrative costs and other.

In equation 4 , the division of debt into long term funding and short term funding with a one year threshold may seem arbitrary, but this threshold is important not only in Basel III (for example, in the calculation of Net Stable Funding Ratio) but also for the purpose of more precise calculation of interest expense and funding costs. In published annual reports interest expense (IE) is reported as one number even though it is generated by a number of different liability components. The interest expense is calculated as follows:

$$
I E=r_{D} \cdot D e p+r_{S T} \cdot\left(I B F+\operatorname{Tr} L+D_{t} \cdot \beta_{t}\right)+r_{L T} \cdot D_{t} \cdot\left(1-\beta_{t}\right),
$$


where $r_{D}=$ cost of deposits,

$r_{S T}=$ cost of short term debt maturing within one year,

$r_{L T}=$ cost of long term debt.

In this study it will be important to distinguish the costs that generate interest expense: cost of deposits, cost of debt maturing within one year and cost of debt maturing above one year.

The cost of deposit is set to value $\mathrm{x} \%$. For example, if cost of deposits is $2 \%$ p.a. then $\mathrm{x}=0.02$, while the cost of short term debt is cost of deposits plus $100 \mathrm{bps}$ and cost of long term debt is cost of deposits plus 200 bps (see equations 6 to 9). The figures (spreads) are arbitrary, they are model parameters and they can be changed. For the purpose of this paper we set the spreads as follows:

$$
\begin{aligned}
& r_{D}=x . \\
& r_{S T}=x+0.01 . \\
& r_{L T}=x+0.02 .
\end{aligned}
$$

We have chosen the specific model values based on the CNB (2013d) quarterly interest rate statistics from the last 18 months, hence the April 2012 - September 2013 period. The average spread between the CNB repo rate (an approximation of $\mathrm{rD}$ ) and interest rate for household deposits with maturity up to one year (an approximation of rST) totalled $0.9 \%$. In addition, average spread between the interest rate for household deposits with maturity up to one year (the approximation of rST) and interest rate for household deposits with maturity over one year (an approximation of rLT) totalled $1.1 \%$. Hence the chosen model values are realistic. The chosen interest rate spreads generate an upward sloping yield curve.

The specific value of " $\mathrm{x}$ " can be calibrated for every bank by solving the equations 5 to 8 . As noted by King (2010), the lowest cost of deposits is consistent with the existence of deposit insurance schemes, which lowers the risk of deposits in comparison with other sources of bank funding.

The final source of bank funding is shareholders' equity. The cost of equity is defined as return on equity (ROE), which is the ratio of net 
income (NI) to equity (Eq). ROE measures the amount of profit in dollars that is generated in a given year per one dollar of shareholders' equity.

$$
\begin{aligned}
& r_{\text {Equity }}=R O E=\frac{N I}{E q}, \\
& \text { where } \begin{aligned}
r_{\text {Equity }} & =\text { cost of equity } \\
R O E & =\text { return on equity }
\end{aligned}
\end{aligned}
$$

As noted by King (2010), while ROE may be quite volatile in the short term, in the long term it provides a good estimate of the return expected by bank shareholders.

When making comparison of funding costs, in line with equations 6 to 8 and in consistency with the classical work of Miller and Modigliani (1958), the deposits are the cheapest form of funding, followed by shortterm debt and long-term debt. The most expensive source of bank funding is equity as it has the smallest residual claim on bank assets.

$$
r_{D}<r_{S T}<r_{L T}<r_{E q u i t y}
$$

Accounting capital (and ratios) should be distinguished from regulatory capital (and ratios). The BankScope database contains total capital ratios for all individual banks.

$$
\begin{aligned}
& \text { TotalCapit alRatio }=\frac{E}{R W A}, \\
& \text { where } \begin{aligned}
E \quad= & \text { regulatory capital, } \\
R W A & =\text { risk weighed assets. }
\end{aligned}
\end{aligned}
$$

Given the relationships in equations 1 to 11 we can calculate the impact of higher capital requirements on interest rates. We assume that in order to meet a target capital ratio (increase by 1 percentage point) the quantity of shareholders' equity is increased relative to RWA.

We hold volume, composition and riskiness of assets constant. From this follows that RWA is held constant as well. However, in order to meet higher capital ratio the relative share of total liabilities to shareholders equity changes. As noted by King (2010), an increase of the capital ratio by 1 percentage point will lead to a smaller rise in shareholders' equity. 
This is caused by RWA, which are typically smaller than total assets (equation 12).

$$
E_{t+1}=E_{t}+\Delta \text { TotalCapitalRatio } \cdot R W A_{t+1},
$$

The increase in the quantity of equity is offset by a decrease in the quantity of liabilities. We assume that the most expensive form of liabilities is offset, hence long-term debt (equation 13).

$$
\Delta D=-\Delta E q
$$

The increase in the quantity of capital at the expense of long-term debt has a number of effects. First, banks' average cost of capital rises as a more expensive one substitutes a cheaper form of funding. On the other hand, net income increases as interest expense falls. Interest expense falls because the relative size of long-term debt is smaller. However, ROE falls (equation 9) as the increase in net income (numerator of the ROE ratio) is smaller than the increase in shareholders' equity (denominator of the $\mathrm{ROE}$ ratio).

Banks want to respond to a fall in ROE. They can take a number of measures. They can redirect their activities to more profitable products, increase non-interest income via commissions and fees or reduce personnel costs and administrative costs. The bank management may decide to take a mixture of these measures or it may even absorb a partial fall in ROE. However, in this study we assume that shareholders do not want to absorb a fall in ROE, they want to get it back to pre-regulatory levels. The bank management decides to take only one measure to achieve that goal: it increases net income by increasing the lending spread $(\alpha)$ charged on loans. Later in the paper we will relax this strict assumption, because usually the bank management has a great variety of choices. However, first we will keep the assumption in order to estimate the maximum impact on lending spreads.

The magnitude of $\alpha$ is determined such that the increase in loan interest income exactly offsets the initial increase in cost of capital so that ROE returns to pre-regulatory levels.

$$
\alpha=\frac{L I I_{t+1}-L I I_{t}}{L o_{t+1}},
$$


When combining equations 3,9 and 14 , we get a final measure of the rise in lending spreads needed to offset the fall in ROE associated with 1 percentage point increase in capital ratio.

$$
\alpha=\frac{\left[\frac{R O E_{t+1} \cdot E_{t+1}}{1-t a x}-\left(O I I_{t+1}+N I I_{t+1}-I E_{t+1}-O E_{t+1}\right)\right]-L I I_{t}}{L o_{t+1}},
$$

Sun, Hoon and Wonhong (2012) note (and we will see later in the results in table 4 as well) that, as long as long-term debt is replaced by equity and the costs of debt and equity remain constant, the increase in lending spreads rises linearly with the increase in capital ratio. If a bank decides to replace cheaper forms of liabilities than long-term debt (for example, short-term debt) with more expensive equity, the rise in lending spreads is higher because the fall in interest expense is relatively lower.

\subsection{Data}

For our analysis we are using the BankScope database, which is a comprehensive, global database with banks' financial statements. BankScope contains information on over 30000 banks. Balance sheets, income statements, interim reports and other information (regulatory capital, financial ratios and ratings) of more than 8000 European banks and 15000 US banks are included in the database with information up to the last 16 years. As our primary focus is Czech banks, we have checked that all of them are included as well. The latest data for Czech banks that are available from the database are the financial reports as of December 2012.

As noted in chapter 2, our analysis is focused on those Czech banks that are under regulatory pressure. These banks need to increase their capital due to Basel III. Our methodology is in contrast to other literature like King (2010) or Sun, Hoon and Wonhong (2012) who included all banks from a chosen region (for example USA) in their sample. Even banks that had very high capital ratios were included. For example King (2010) excluded only banks with very high capital ratios over $100 \%$ ( $8 \%$ is regulatory minimum). 
We assume that banks with very high capital ratios have little motivation to increase their capital levels even further as they already meet tighter capital requirements. Therefore our analysis applies only to those banks that are under regulatory pressure as these are the ones that are motivated to increase their capital. These are the banks that may be motivated to increase their lending spreads and net income in order to get capital to the required level.

The banks under regulatory pressure can be identified in several ways. We will adopt a simple approach wherein the bank is under regulatory pressure if the bank's capital is below the $13 \%$ level. The $13 \%$ capital ratio is arbitrary. It consists of $8 \%$ regulatory minimum, $2.5 \%$ conservation capital and $2.5 \%$ countercyclical buffer. We set the ratio to $13 \%$, as this is the level of capital when a bank does not feel any regulatory pressure to increase its capital and simultaneously, the bank is fully prepared for a potential increase in countercyclical buffer, which is currently set to $0 \%$. As noted introduction, the regulator may raise the countercyclical buffer to as high as $2.5 \%$ in 2016.

As the top four Czech banks (ČSOB, Česká spořitelna, Komerční banka and UniCredit Bank) also face a SIFI surcharge of 1 to $3 \%$ (see chapter 1.1 ), the $13 \%$ threshold needs to be increased to $14-16 \%$ for these four banks.

According to the Czech National Bank (2013c) statistics, as of December 2012 there were 23 commercial banks (including five building societies) and 20 foreign bank branches operating in the Czech Republic, hence 43 banks in total The total assets of the Czech banking sector stood at CZK 4.633 billion at the end of 2012.

The structure is fairly stable, however, from a long-term perspective. Four large banks (by current methodology over CZK 250 billion in assets) managed approximately $52.4 \%$ of gross loans and $58.3 \%$ of deposits. As noted in the Czech Banking Association (2013) report, all competition indicators reflect an environment of healthy competition among Czech banks.

The list of 23 commercial banks is a starting point for our analysis. We omit foreign bank branches, as they do not hold equity. The average capital adequacy of the 23 banks was $18.0 \%$ as of 2012 year-end. Chart 2 shows the capital adequacy of all individual banks in relation to their size. 
Matejašák, M.: Basel III: Will Borrowing Money from Czech Banks Become More Expensive?

Fig. 2: Total assets and capital adequacy of Czech banks as at December 2012

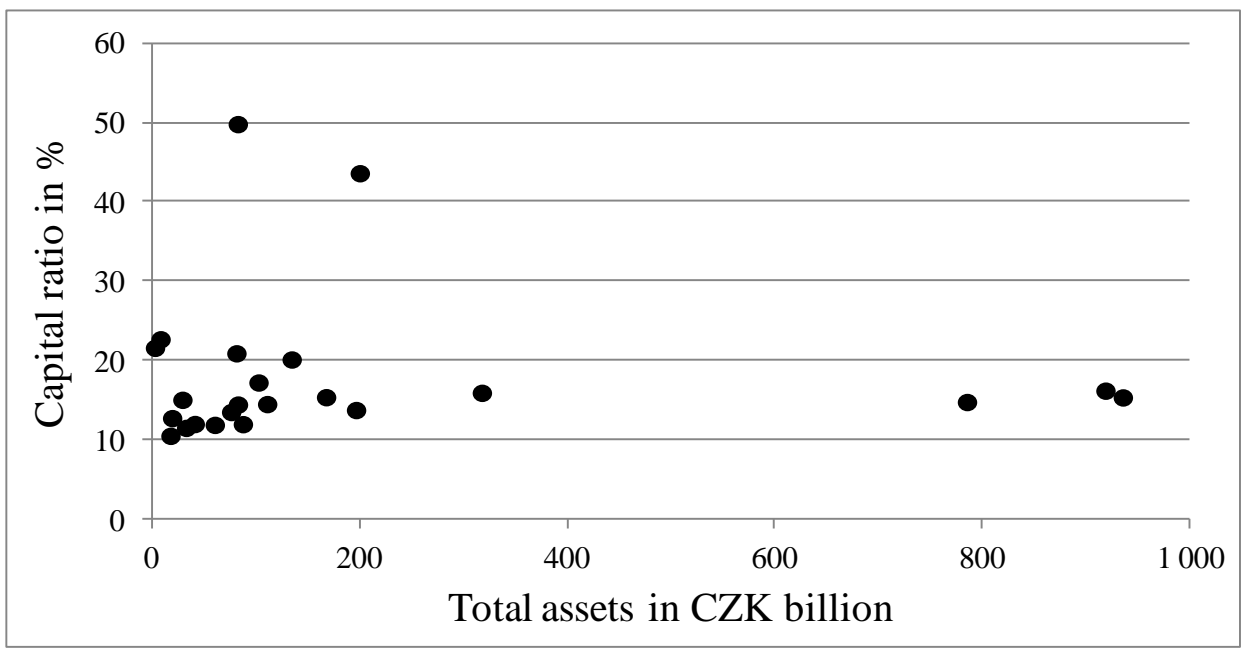

Source: BankScope, author's calculations.

Chart 2 shows that the banks with the lowest capital ratios are the smallest banks with total assets below CZK 100 billion.

According to the latest publicly available data on capital adequacy, only six banks had a capital ratio below the $13 \%$ threshold as of September 2013. Table 2 lists the six banks together with their total assets and capital ratios as of September 2013. Average total assets and average capital ratio of the six banks totalled CZK 61 billion and $11.6 \%$ respectively. Further analysis will be focused only on these six banks, as these are the banks with capital ratios below the $13 \%$ threshold. The following six banks are the banks under regulatory pressure. 
Tab. 2: Capital ratios and size of banks under regulatory pressure

\begin{tabular}{|l|r|r|}
\hline \multicolumn{1}{|c|}{ Name } & $\begin{array}{c}\text { Total Capital Ratio } \\
\text { as at September } \\
\mathbf{2 0 1 3} \text { in \% }\end{array}$ & $\begin{array}{c}\text { Total assets as } \\
\text { at Sept. 2013 } \\
\text { in CZK billion }\end{array}$ \\
\hline J\&T BANKA & 12.97 & 95.5 \\
\hline PPF banka & 12.51 & 108.6 \\
\hline Sberbank CZ & 11.40 & 65.0 \\
\hline Wüstenrot hypoteční banka & 11.29 & 27.0 \\
\hline Fio banka & 10.89 & 24.5 \\
\hline Air bank & 10.80 & 48.1 \\
\hline
\end{tabular}

Source: Quarterly financial statements of the banks as at 30.9.2013.

When looking at the top four banks, all four banks passed their $14 \%$ $16 \%$ threshold, which includes the SIFI surcharge. Their average capital adequacy totalled $16.5 \%$ as of September. 2013. We omit these four banks from further analysis as well as they are under no regulatory pressure and they are fully prepared for an increase in the countercyclical buffer as well.

After identification of the banks under regulatory pressure, a representative balance sheet and income statement is constructed for the six banks in the sample. For that purpose we will use the BankScope database to extract a balance sheet, income statement and regulatory ratios for each of the six banks. Then we will construct a representative balance sheet and income statement by taking the weighted average values of individual components. The weights are based on total assets. Table 3 shows the stylized balance sheet and income statement for the representative bank. All items are shown as \% of total assets. 
Matejašák, M.: Basel III: Will Borrowing Money from Czech Banks Become More Expensive?

Tab. 3: Representative financial statements as at December 2012

\begin{tabular}{|c|c|c|c|}
\hline Balance sheet & Average & Income statement & Average \\
\hline Cash and balances at Central Banks & 9.3 & Interest income & 3.88 \\
\hline InterBank claims & 10.3 & Interest expense & 1.93 \\
\hline Trading assets & 5.3 & A. Net interest income & 1.96 \\
\hline Net loans & 49.7 & Trading income & 0.52 \\
\hline Investments and securities & 23.7 & Fees, comissions & 0.54 \\
\hline Other assets & 1.8 & B. Non interest income & 1.06 \\
\hline Total Assets & 100.0 & C. Total revenue $(\mathrm{A}+\mathrm{B})$ & 3.02 \\
\hline Deposits & 73.2 & Personnel expense & 0.62 \\
\hline Interbank funding & 6.4 & Other administrative costs & 1.61 \\
\hline Trading liabilities & 2.0 & D. Total operating expense & 2.22 \\
\hline Debt (Wholesale funding) & 6.6 & E. Operating profit (C-D) & 0.79 \\
\hline Other liabilities & 4.1 & F. Tax & 0.16 \\
\hline Total Liabilities & 92.2 & G. Net income & 0.63 \\
\hline Total Equity & 7.8 & & \\
\hline Total Liabilities and Equity & 100.0 & $\operatorname{ROE}(\%)$ & $8.1 \%$ \\
\hline Total capital ratio & 11.9 & $\begin{array}{l}\text { Leverage multiple = } \\
\text { Total assets/Equity }\end{array}$ & 12.9 \\
\hline RWA/Total assets & 50.4 & Average effective tax rate $(\%)$ & $21 \%$ \\
\hline
\end{tabular}

Source: Author's calculations.

Loans represent about half of total assets, followed by investments $(23.7 \%)$ and interbank claims $(10.3 \%)$. These are usually financed by deposits $(73.2 \%)$, equity $(7.8 \%)$, wholesale funding $(6.6 \%)$ and interbank funding $(6.4 \%)$. Risk weighted assets amount to $50.4 \%$ of total assets. This is an important ratio, as it tells us that an increase on capital ratio by 1 percentage point requires a rise in shareholder equity of only half a percentage point.

When looking at the consolidated income statement in table 3 , net interest income is the main source of net income. Net interest income totals $1.96 \%$ and non-interest income $1.06 \%$. Total operating expense totals $2.22 \%$ and net income around $0.63 \%$ of total assets. This implies an average return on equity of $8.1 \%$. The average tax rate is $21 \%$. 


\section{Impact of higher capital requirement}

Chapter 3 presents our findings. First, we will present the results in a basic scenario where we assume that shareholders do not want to absorb any fall in ROE. Later we will leave this assumption and present the results where shareholders allow a fall in ROE.

\subsection{Impact of 1 percentage point increase in the capital ratio on lending spreads}

Table 4, column A presents the results of our calculations ${ }^{1}$. It assumes the following are all valid: that a representative bank wants to increase its capital level, that it does not want its ROE to fall, it does not want to change the structure and riskiness of its assets, it substitutes long-term debt by equity, the cost of debt remains unchanged and the bank wants to increase net income only by increasing lending spread (and not by other means such as reducing operational expense). Given these assumptions, we can conclude that an increase in capital ratio by 1 percentage point leads to an increase in lending spread by 6.3 basis points.

Tab. 4: Impact of 1 percentage point increase in capital on interest rate assuming changes in ROE and no change in cost of debt

\begin{tabular}{|c|cccc|}
\hline & $\mathrm{A}$ & $\mathrm{B}$ & $\mathrm{C}$ & $\mathrm{D}$ \\
\hline $\begin{array}{c}\text { Increase in } \\
\begin{array}{c}\text { Capital ratio } \\
\text { (in percentage } \\
\text { points) }\end{array}\end{array}$ & $\begin{array}{c}\text { No change } \\
\text { in ROE }\end{array}$ & $\begin{array}{c}\text { ROE } \\
\text { falls by 5 } 5 \\
\text { basis } \\
\text { points }\end{array}$ & $\begin{array}{c}\text { ROE falls } \\
\text { by 10 } \\
\text { basis } \\
\text { points }\end{array}$ & $\begin{array}{c}\text { ROE } \\
\text { falls by } \\
15 \text { basis } \\
\text { points }\end{array}$ \\
\hline \multicolumn{4}{|c|}{ Increase in lending spread in basis points } \\
\hline 1 & 6.3 & 5.2 & 4.2 & 3.1 \\
3 & 12.5 & 10.4 & 8.3 & 6.2 \\
& 18.8 & 15.6 & 12.5 & 9.4 \\
\hline
\end{tabular}

Source: Author's calculations.

Columns B to D will be explained later in the chapter. They present scenarios where ROE is allowed to fall. 
Note that the relationship between an increase in capital ratio and a rise in lending spread is linear. For example, if a bank wants to raise capital ratio by 2 percentage points, than the increase in lending spreads amounts to 12.5 basis points. If we compare our results with the previous literature listed in table 1, we can conclude that the impact of Basel III on banks in the Czech Republic with 6.3 basis points increase in lending spreads is low.

The major factors that affect the lending spreads are the ratio of RWA to total assets (the lower the ratio, the smaller the impact on lending spreads), the relative size of loan to total assets (the higher the relative size of loans to total assets, the lower the impact) or the long- term interest rate on debt (the higher interest rate, the lower impact) ceteris paribus.

Table 5 shows our calculation in more detail. Column A shows the initial position of the representative bank with its liabilities and equity, complete income statement and initial ROE. Assets are not shown, as there is no change during the process of accommodation. Column $\mathrm{B}$ shows the change in quantities of capital and long-term debt and the resulting decrease in interest expense. The equity increases by 0.5 , which is the required increase in order to raise capital ratio from the initial $11.9 \%$ to the desired $12.9 \%$. Column C shows the financial statements after the increase in capital. We can see that net income increases from $0.63 \%$ to $0.65 \%$, however, ROE falls from $8.08 \%$ to $7.83 \%$. Hence, the accommodation process continues and column D shows the required increase in interest income to get ROE back to its pre-regulatory level of $8.08 \%$. The required increase in interest income totals 0.03 basis points, which is achieved by a rise in lending spread by 6.3 basis points.

It is worth to mention that our methodology used for estimating the changes in spreads is likely to give higher estimates because it abstracts from competition by those banks, which are not under "under regulatory pressure", 17 out of 23 banks had a capital ratio above the $13 \%$ threshold. The banks with capital, which is higher than future capital requirements, compete directly with the banks under regulatory pressure and this will tend to mitigate eventual changes in spreads. 
Tab. 5: Calculation of rise in lending spreads for 1 percentage point increase in capital ratio assuming no change in $\mathrm{ROE}$ and cost of debt

\begin{tabular}{|c|c|c|c|c|c|}
\hline & $\mathrm{A}$ & $\mathrm{B}$ & $\mathrm{C}=\mathrm{A}+\mathrm{B}$ & $\mathrm{D}$ & $\mathrm{E}=\mathrm{C}+\mathrm{D}$ \\
\hline & $\begin{array}{c}\text { Initial } \\
\text { position }\end{array}$ & $\begin{array}{l}\text { Change 1: } \\
\text { Increase in } \\
\text { equity and no } \\
\text { change in }\end{array}$ & $\begin{array}{c}\text { Position } \\
\text { after } \\
\text { change } \\
1\end{array}$ & $\begin{array}{l}\text { Change 2: } \\
\text { Increase } \\
\text { in lending } \\
\text { spreads }\end{array}$ & $\begin{array}{l}\text { Change 2: } \\
\text { Position after } \\
\text { increase of } \\
\text { lending }\end{array}$ \\
\hline & \multicolumn{5}{|c|}{$\%$ of total assets } \\
\hline \multirow{3}{*}{$\begin{array}{l}\text { Increase in lending spread } \\
\text { RWA/Total assets } \\
\text { Total capital ratio }(\%)\end{array}$} & & 0.0 & & 6.3 & \\
\hline & 50.4 & 0.0 & 50.4 & 0.0 & 50.4 \\
\hline & 11.9 & 1.0 & 12.9 & 0.0 & 12.9 \\
\hline Deposits & 73.2 & 0.0 & 73.2 & 0.0 & 73.2 \\
\hline Interbank funding & 6.4 & 0.0 & 6.4 & 0.0 & 6.4 \\
\hline Trading liabilities & 2.0 & 0.0 & 2.0 & 0.0 & 2.0 \\
\hline Debt (Wholesale funding) & 6.6 & -0.5 & 6.1 & 0.0 & 6.1 \\
\hline Other liabilities & 4.1 & 0.0 & 4.1 & 0.0 & 4.1 \\
\hline Total Liabilities & 92.2 & 0.0 & 92.2 & 0.0 & 92.2 \\
\hline Total Equity & 7.8 & 0.5 & 8.3 & 0.0 & 8.3 \\
\hline Total Liabilities and Equity & 100.0 & 0.0 & 100.0 & 0.0 & 100.0 \\
\hline \multicolumn{6}{|l|}{ Income statement } \\
\hline Interest income & 3.88 & 0.00 & 3.88 & 0.03 & 3.92 \\
\hline Interest expense & 1.93 & -0.02 & 1.91 & 0.00 & 1.91 \\
\hline A. Net interest income & 1.96 & 0.02 & 1.98 & 0.03 & 2.01 \\
\hline Trading income & 0.52 & 0.00 & 0.52 & 0.00 & 0.52 \\
\hline Fees, comissions & 0.54 & 0.00 & 0.54 & 0.00 & 0.54 \\
\hline B. Non interest income & 1.06 & 0.00 & 1.06 & 0.00 & 1.06 \\
\hline C. Total revenue $(\mathrm{A}+\mathrm{B})$ & 3.02 & 0.02 & 3.04 & 0.03 & 3.07 \\
\hline Personnel expense & 0.62 & 0.00 & 0.62 & 0.00 & 0.62 \\
\hline Other administrative costs & 1.61 & 0.00 & 1.61 & 0.00 & 1.61 \\
\hline D. Total operating expense & 2.22 & 0.00 & 2.22 & 0.00 & 2.22 \\
\hline E. Operating profit (C-D) & 0.79 & 0.02 & 0.81 & 0.03 & 0.84 \\
\hline F. Tax & 0.16 & 0.00 & 0.16 & 0.01 & 0.17 \\
\hline G. Net income & 0.63 & 0.02 & 0.65 & 0.02 & 0.67 \\
\hline ROE (\%) & $8.08 \%$ & $-0.25 \%$ & $7.83 \%$ & $0.25 \%$ & $8.08 \%$ \\
\hline
\end{tabular}

Source: Author's calculations. 


\subsection{Impact of 1 percentage point increase in capital ratio on lending spreads if ROE is allowed to fall}

So far we have been conservative and we have assumed no fall in ROE. We have assumed that the bank wants to keep its ROE at its initial level even though the leverage has decreased. The theory suggests that ROE may fall as the leverage and riskiness of the representative bank falls. We can find the theoretical basis for the fall in ROE in Miller and Modigliani's (1958) theory, which suggests that the expected ROE of an unleveraged firm should be lower than the ROE of a leveraged firm. The theory deals primarily with a firm, not a bank, but we cannot a priori reject its applicability to banks. We believe it is worth exploring the impact on lending spreads if the ROE is allowed to fall. We assume three additional scenarios in which the ROE falls by 5,10 or 15 basis points. For results see table 4, columns B to D.

The calculation results show that the impact on lending spreads is smaller if a partial fall in ROE is allowed. For example, the scenario of a 1 percentage point increase in capital ratio leads to an increase in interest rates of 6.3 basis points if ROE remains constant. On the other hand, the rates increase only by 3.1 basis points if ROE is allowed to fall by 15 basis points. Relaxing constant ROE has a major effect on final lending spreads. These findings are interesting for analysis of assumptions sensitivity, as constant ROE is one of the assumptions.

Future research on this topic can be broadened in a number of ways. This paper is a starting point and we can relax a number of assumptions in future research. For example, the bank reacts to tightened regulation by a mix of measures, not only by an increase in interest rates. It may simultaneously increase interest rates, reduce operational expenditure and change the structure of assets. A mix of measures is closer to reality. This would lead to another decrease in the impact on lending spreads from starting $6.3 \%$, which is already quite a low figure. Alternatively, we could use long-term ROE rather than the most-recently reported ROE in order to decrease the volatility of our estimate.

Overall, we can conclude that the possible impact of tighter capital regulation on interest rates in the Czech Republic is small. The majority of Czech banks hold capital adequacy far above the required minimum. Out of 23 banks only six banks have capital ratio below $13 \%$, hence these six banks may feel regulatory pressure in future, as they are not 
fully prepared for a potential increase in the countercyclical buffer. If these banks decide to increase their capital level by raising interest rates, to prevent ROE from falling, the impact will be slight. The interest rates in these six banks will rise by roughly 6.3 basis points.

\section{Conclusion}

In this paper we have analysed a common concern that is raised with the implementation of Basel III (and hence CRD IV/CRR) and tighter capital regulation in the Czech Republic. The concern is that borrowing money from Czech banks will become more expensive. Analysing the data of Czech banks we have provided answers to two key questions: will loans in all Czech banks become more expensive? By how much could lending spreads increase? In order to answer these two key questions we have followed the methodology presented by King (2010).

Our analysis shows that the capital adequacy of Czech banks is at a high level, far above the required regulatory minimum and hence we do not expect any impact of tighter regulation on interest rates in these banks. However, out of a total of 23 banks, there are six banks that are above the required $8 \%$ minimum, but below the $13 \%$ threshold. These six banks may fall under regulatory pressure if the countercyclical buffer is increased from the current $0 \%$ to $2.5 \%$. They will need to increase their capital levels. Therefore, we have targeted our analysis on these six banks. Our calculations show that the impact of tightened regulation on lending interest is rather minor also in these six banks. The higher costs associated with a one percentage point increase in capital ratio can be recovered by increasing lending spreads 6.3 basis points. The change is even smaller if ROE is not constrained to fall. The two major factors that affect the change in lending spreads are the ratio of RWA to total assets and the relative size of loan to total assets ceteris paribus.

In addition, the methodology used for estimating the changes in spreads is likely to give higher estimates because it abstracts from competition by those banks, which are not under "under regulatory pressure". The banks with capital, which is higher than future capital requirements, compete directly with the banks under regulatory pressure and this will tend to mitigate eventual changes in spreads. 
Matejašák, M.: Basel III: Will Borrowing Money from Czech Banks Become More Expensive?

We have treated this study is a starting point for modelling the impact of the new Basel III standard on changes in interest rates, capital levels and risk behaviour of Czech banks.

\section{References}

BIS (2011): Basel III: A Global Regulatory Framework for More Resilient Banks and Banking Systems. [on-line], Basel, Bank for International Settlements, [cited $7^{\text {th }}$ February 2014], <http://www.bis.org/publ/bcbs189.pdf>.

ČBA (2013): Czech Banking Sector 2012/2013. [on-line], Praha, Česká bankovní asociace, [cited $7^{\text {th }}$ February 2014], <https://www.czechba.cz/cs/node/15759>.

ČNB (2013a): Makroobezřetnostní politika: nástroje a indicatory. [online], Praha, Česká národní banka, [cited $7^{\text {th }}$ February 2014], $<$ http://www.mfcr.cz/assets/cs/media/2013-10_Makroobezretnostnipolitika-nastroje-a-indikatory.pdf $>$.

ČNB (2013b): Nová pravidla posilí bankovní stabilitu. [on-line], Praha, Česká národní banka, [cited $7^{\text {th }}$ February 2014], $<$ http://www.cnb.cz/cs/verejnost/pro_media/clanky_rozhovory/media_20 13/cl_13_131021_tomsik_hn.html>.

ČNB (2013c): Ukazatele o bankovním sektoru. [on-line], Praha, Česká národní banka, [cited $7^{\text {th }}$ February 2014], <http://www.cnb.cz/cs/ dohled_financni_trh/souhrnne_informace_fin_trhy/zakladni_ukazatele_fi n_trhu/banky/index.html>.

ČNB (2013d): Úrokové sazby v ČR. [on-line], Praha, Česká národní banka, [cited $7^{\text {th }}$ February 2014], <http://www.cnb.cz/cs/statistika /menova_bankovni_stat/harm_stat_data/index.html\#B $>$.

Dvořák, P. (2010): Předmluva - Co můžeme očekávat od Basel III? Český finanční a účetní časopis, vol. 5, no. 3, pp. 4-5.

Elliott, D. J. (2010): A Further Exploration of Bank Capital Requirements: Effects of Competition from Other Financial Sectors and Effects of Size of Bank or Borrowers and Loan Type. [on-line], Washington, The Brookings Institutions, [cited $7^{\text {th }}$ February 2014], $<$ http://www.brookings.edu/ /media/research/files/papers/2009/9/24\%20c apital\%20elliott/0924_capital_elliott.pdf>. 
Kashyap, K. - Stein, J. - Hanson, S. (2010): An Analysis of the Impact of 'Substantially Heightened' Capital Requirements on Large Financial Institutions. [on-line], [cited $7^{\text {th }}$ February 2014], <http://chifl.shufe.edu.cn/upload/htmleditor/File/12091610241.pdf>.

King, M. R. (2010): Mapping capital and liquidity requirements to bank lending spreads. [on-line], BIS Working Papers 324, Basel, Bank for International Settlements, [cited $7^{\text {th }}$ February 2014], <http://www.bis.org/publ/work324.pdf>.

Mandel, M. - Tomšík, V. (2011): Regulace bankovniho sektoru z pohledu ekonomické teorie. Politická ekonomie, vol. 59, no. 1, pp. 58-81.

Musílek, P. (2011): Trhy cenných papírü. Praha, Ekopress, 2011.

Modigliani, F. - Miller, M. H. (1958): The Cost of Capital, Corporation Finance, and the Theory of Investment. [on-line], American Economic Review, 48(3), [cited 7th February, 2014], <https://www2.bc.edu/ $\sim$ chemmanu/phdfincorp/MF891\%20papers/MM1958.pdf>.

Roger, S. - Vlček, J. (2011): Macroeconomic Costs of Higher Bank Capital and Liquidity Requirements. [on-line], IMF Working Paper no. 11/103, Washington, International Monetary Fund, 2011, [cited $7^{\text {th }}$ February 2014], <http://www.imf.org/external/pubs/ft/wp/2011/wp11103 .pdf>.

Slovik P, - Cournede, B. (2011): Macroeconomic Impact of Basel III. [on-line], OECD Economics Department Working Papers, no. 844, OECD Publishing, [cited $7^{\text {th }}$ February 2014], <http://dx.doi.org/ 10.1787/5kghwnhkkjs8-en>.

Sun, E. C. - Hoon, K. - Wonhong, K. (2012): The Impact of Strengthened Basel III Banking Regulation on Lending Spreads: Comparisons across Countries and Business Models. [on-line], BOK Working paper No. 2012-15, Soul, Bank of Korea, [cited $7^{\text {th }}$ February 2014], <http://eng.bok.or.kr/down.search?file_path=/attach/imer_eng/ 1287/2012/12/1356076144575.pdf\&file_name=BOK+Working + Paper $+\mathrm{N}$ o.2012-15+The+Impact+of+Strengthened+Basel+III+Banking+ Regulation+on+Lending+Spreads.pdf >.

Š́torová, B. - Teplý, P. (2013): The Impact of Basel III on Lending Rates of EU Banks. Finance a úvěr, vol. 63, no. 3, pp. 226-243.

Patria (2013): ¿̌NB zvolila čtyři systémové banky, u kterých bude požadovat vyšši kapitál. [on-line], Praha, Patria, [cited $7^{\text {th }}$ February 2014], 
Matejašák, M.: Basel III: Will Borrowing Money from Czech Banks Become More Expensive?

<http://www.patria.cz/zpravodajstvi/2465739/cnb-zvolila-ctyri-syste move-banky-u-kterych-bude-pozadovat-vyssi-kapital.html>. 


\title{
Basel III: Will Borrowing Money from Czech Banks Become More Expensive?
}

\begin{abstract}
We estimate the required increase in banks' lending spreads assuming that banks under regulatory pressure would raise lending spreads to prevent ROE from falling when the capital regulation is tightened. We focus our analysis on six Czech banks that are under regulatory pressure, and are therefore the ones most affected by the increased capital requirement. We follow the mapping methodology presented by King (2010). We find that the required increase in lending spreads to keep ROE from falling totals 6.3 basis points. We conclude that the impact of tightened capital regulation on lending spreads in the Czech banking sector is minor. If shareholders decide to absorb some of the fall in ROE, or they take other measures to prevent a fall in ROE, the potential impact on lending spreads will be even smaller.
\end{abstract}

Key words: Basel III; Capital adequacy; Capital requirement; Lending spreads.

JEL classification: $\quad$ G28 